\title{
Functional distribution of income and economic activity in Croatia: Post-Keynesian approach*
}

\author{
Boris Vujčić ${ }^{1}$, Milan Deskar-Škrbić ${ }^{2}$, Zvonimir Ratkovski ${ }^{3}$, Jurica Zrnc ${ }^{4}$
}

\begin{abstract}
The aim of this paper is to quantify the effects of changes in functional income distribution on selected macroeconomic variables in Croatia in period from 2000-2012. We use structural VAR approach with identification scheme based on a priori restrictions that are derived from theoretical framework of Post-Keynesian macroeconomic model. Our main hypothesis, which is confirmed in the empirical analysis, is that the accumulation of capital in Croatia was primarily determined by income from labor, i.e. that Croatia had wage-led accumulation. We also found that labor market dynamics was dominantly influenced by demand side shocks and that positive effects of the rise in exports, resulting from the gain in competitiveness (after reducing wage share in income) outweigh negative effects of weaker demand on the capacity utilization. So in our opinion export share increase should become policy priority, as domestic demand is currently constrained by high private and public debt levels. To the extent that increase in exports might require decline in the relative share of labor, negative impact on the investments in non-tradable sector would need to be offset with higher investments in tradable sector of Croatian economy.
\end{abstract}

Key words: functional distribution of income, Post-Keynesian macroeconomic model, Croatian economy, SVAR

JEL classification: E12, E21, E25

* Received: 25-02-2013; accepted: 06-06-2014

1 PhD, Governor, Croatian National Bank, Trg hrvatskih velikana 3, 10000 Zagreb, Croatia; Associate Professor, University of Zagreb, Faculty of Economics and Business, Trg J. F. Kennedyja 6, 10000 Zagreb, Croatia. Scientific affilation: EMU, eurization, EU labour market. Phone: 014564 555.E-mail: boris.vujcic@hnb.hr.

${ }^{2}$ MA, Macroeconomic Analyst, Erste\&Steiermarkische bank d.d., Ivana Lučića 2, 10000 Zagreb, Croatia. Scientific affilation: macroeconomics of financial markets, economic policy, public finance and banking. Phone: 091580 2592.E-mail:mdskrbic@erstebank.com.

${ }^{3}$ MA, Analyst, Deloitte Croatia, Radnička cesta 80, 10000 Zagreb, Croatia. Scientific affilation: macroeconomics, heterodox economic theory, economic policy. Phone: 0981871 839. E-mail: zvonimir.ratkovski@gmail.com.

${ }^{4}$ MA, Researcher, Croatian National Bank, Trg hrvatskih velikana 3, 10000 Zagreb, Croatia. Scientific affilation: macroeconomics, economic growth, labor economics, economic history. Phone: 098959 3482.E-mail: jurica.zrnc@hnb.hr. 


\section{Introduction}

This paper presents and empirically evaluates a Post-Keynesian macroeconomic model that explores the interdependence of labor market trends, domestic demand, international trade and economic growth in Croatia. The model belongs to the group of heterodox macroeconomic models, whose theoretical assumptions differ substantially from traditional models, which largely ignore the effects of the functional distribution of income, i.e. - the share of national income between labor and capital in economic activity. One of the fundamental assumptions of heterodox economic models is that workers have a higher propensity to consume than investors do and that most of the income of workers is channeled to current consumption, while investors defer spending for future investments, which has different impact on aggregate demand.

From the Post-Keynesian perspective, functional distribution of income is linked to the long-term trends in the aggregate demand and economic growth in an economy. Uneven distribution of income between labor and capital (in favor of profits) may weaken middle income class purchasing power and lead to contraction of aggregate demand and hence economic growth. On the other hand, higher profit shares mean higher return and higher retained earnings, which can lead to investment spending by private sector, accumulation of capital and, consequently, economic growth. The net effect on economic growth depends on the strength of each of these mechanisms and can vary between countries or time periods.

If capital accumulation responds positively to the growth of share of profits in national income it can be said that capital accumulation is initiated by income from capital, i.e. profit-led accumulation. On the other hand, if an increase in the share of profits in national income reduces capital accumulation, because of a decrease in the wage bill and the purchasing power of the workers, it can be said that capital accumulation is initiated by incomes from labor, i.e. wage-led accumulation. Besides capital accumulation, functional income distribution can affect the degree of capacity utilization in an economy. If the increase in the share of profits has a positive effect on the degree of capacity utilization it can be said that the economy has accelerating growth regime, while otherwise stagnant growth regime. Although it seems that these are synonyms, it is important to emphasize that the effect of the functional distribution of income on capital accumulation and the degree of capacity utilization may be different in some cases.

Because the main growth factor in Croatia through 2000s was private consumption, accompanied by large investment in house building (which is the consequence of strong demand from households) our main hypothesis is that the accumulation of capital in Croatia was primarily determined by income from labor, i.e. that Croatia had wage-led accumulation. We will also estimate the effects of changes in profit and labor shares in income on capacity utilization and labor market and try to 
determine whether Croatia had stagnationist or accelerationist growth regime and which shocks had greater impact on labor market movements, demand side or supply side.

The contribution of this research and the results should be reflected in the fact that it represents the first attempt of the analysis of the functioning and relationships within the Croatian economy in the heterodox macroeconomic framework and that it provides first empirical assessment of the effects of functional distribution of income on economic activity in Croatia.

The second section provides an overview of recent literature, with special emphasis on papers with an empirical analysis. The third section presents and explains theoretical framework of analysis and assumptions for the empirical model. The fourth section briefly explains the econometric method used in this paper, sources and characteristics of data. After the results in the fifth part of the paper, in section six discussion and conclusion are presented.

\section{Literature review}

The model proposed by Bhaduri and Marglin (1990) is the beginning point of most Post-Keynesian models which describe the interrelationship between the functional distribution of income, unemployment, real wages and economic growth. They concentrate on the Keynesian and Kaleckian theoretical approach and the importance of effective aggregate demand versus supply. The framework they develop emphasizes real wages as an important segment of demand, and not only as a major component of supply cost. This model represents a theoretical basis for a number of empirical research articles which estimate the impact of functional distribution of income on economic activity.

The first paper which approached the econometric estimation of the Bhaduri and Marglin model is Bowles and Boyer (1995). Their empirical model is based on separately estimated savings, investment and net exports functions in order to capture the marginal effects of these macroeconomic aggregates. The main flaw in this paper is that the characteristics of the time series are not tested. There are no unit root tests, so it is not known if the estimated parameters in the model have desired statistical properties. For this reason the results of this paper will not be discussed. An econometrically more suitable model is Gordon (1995a), who estimated a VAR model for investment and consumption as functions of income distribution. Gordon (1995b) extends the model to incorporate open economy and concludes that USA has a profit-led growth regime.

Onaran and Stockhammer (2005) estimate a structural VAR model for Turkey and Korea which takes into account the theoretical relations between variables. The 
variables they use differ somewhat from the original model, due to availability of data and specific experiences of these countries. The authors point out that both countries have tried to spur growth by export expansion, but in different ways. Turkey based its strategy on the usual recommendations of the IMF and the World Bank - the reduction of bargaining power of labor and the reduction of wages. On the other hand, South Korea based its growth on industrial policy and the government control of the financial sector. The results show that the increase in the profit share does not increase accumulation, growth and employment in both countries. Hence, they conclude, that neither country has a profit-led growth regime.

Stockhammer and Onaran (2004) estimate a similar model for USA, Great Britain and France. They supplement the model with functions which describe income distribution, labor productivity and unemployment. The main conclusion of the empirical model is that unemployment is determined by the labor market, and that the influence of the income distribution on aggregate demand and employment is weak. Also, they find that productivity growth affects positively the profit share.

Perhaps the most comprehensive study of this type is Stockhammer, Onaran and Ederer, (2009). They test a Kaleckian model for the Euro area as whole and specific countries from the Euro area. Firstly, they found that the type of the growth regime depends on the degree of openness of an economy. This is in accordance with the predictions from the theoretical model. The stylized fact of economic growth in Euro-zone is that from 1981 the share of labor fell for $11.6 \%$, the rates of economic growth were lower and unemployment increased. The authors believe that this is the result of the labor cost (wages) reduction which is advocated by the European Union from approximately the same time. The main conclusion is that growth in Euro-zone as a whole is wage led, but in specific countries it is mostly profit led. Thus, although it is probably desirable for each particular country to reduce labor costs, for the euro area as a whole, it has negative effects. In this sense, the insistence on reducing government spending in the EU Member States is a misled strategy.

This econometric model is based on estimation of individual equation for consumption, investment, imports and exports. Equations are mostly estimated by error correction models, and where the statistic characteristics of the model are unsatisfactory the ADL model is used. The main objection to this type of modeling is that the functional income distribution is assumed exogenous, which is not in the spirit of Kaleckian models. Mainly for this reason, this paper analyzes the effect of functional income distribution economic activity using SVAR.

Apart from research that focuses on the identification of the growth regime of a specific economy, there is a segment of literature that goes one step further. Specifically, this strand of research delves into the effects of monetary and fiscal 
policy instruments on the functional income distribution for selected countries. The focus is on short term and long term effects of changes in interest rates by the central bank. For example, Hein and Ochsen (2003), estimate the effect of interest rates in the time period from 1960 to 1995 in France, Germany, Great Britain and USA. They conclude that an increase in interest rates causes a fall in production, investment and profit share in France and Germany, but in Great Britain and USA the effect is positive.

Further developing this methodology, Hein and Schoder (2009) extended the analyzed time period until 2007. This represents a certain advantage in terms of usage of econometric tools. By calculating the interest elasticity of the functional distribution of income they show how the increase in the long term interest rates in USA and Germany causes a reduction in capacity utilization, capital accumulation and profits in absolute terms. In the same time there is income redistribution from labor to capital, and thus an increase in the profit share of income. Given that one of the fundamental goals of this paper is to identify the growth regime of the Croatian economy, the estimation of the influence which certain policy instruments and variables have on income distribution represents future research challenges.

\section{Methodology}

\subsection{Theoretical framework}

The model that appears in this section is based on the Bhaduri-Marglin (1990) model, which has been adjusted for empirical research by Stockhammer and Onaran (2004). In their paper, Bhaduri and Marglin (1990) propose decomposition of savings and profits in a relative form, normalized by capital. Such decomposition is useful because it relates savings rate and profit rate which allows the analysis of the effect of functional income redistribution on savings, capital accumulation and capacity utilization. In addition, by linearizing these relations we arrive at functions used as a framework for empirical estimation.

Therefore, the saving and profit rates take the following form:

$$
\begin{aligned}
& g_{t}^{S}=\frac{S}{K}=s \frac{R}{Y} \frac{Y}{\bar{Y}} \frac{\bar{Y}}{K}=s \pi z k \\
& r=\frac{R}{K}=\frac{R}{Y} \frac{Y}{\bar{Y}} \frac{\bar{Y}}{K}=\pi z k
\end{aligned}
$$

\footnotetext{
5 Additional explanation: $\mathrm{S}$ - savings level; $\mathrm{R}$ - level of profits in the economy; $\mathrm{Y}$ - income/output; $\bar{Y}$ - potential income/output under full capacity utilization; $\mathrm{K}$ - gross physical capital
} 
where: (i) $s$ - the rate of savings from profits $(S / R)$, (ii) $R / Y=\pi$ - profit share, (iii) $Y / \bar{Y}=z$ - capacity utilization and (iv) $\bar{Y} / K=k$ - productivity of capital. $g_{t}^{S}$ represents savings normalized by capital, while $r$ represents the rate of profit. As can be seen from the equation, savings depend on the profit share distribution within national income and on the degree of capacity utilization, assuming constant productivity of capital and constant savings rate. In order to establish a relationship between the variables, these functions will be linearized. Therefore, the linearized form of the savings function is as follows:

$$
g_{t}^{S}=\frac{S}{K}=b_{1} z_{t}+b_{2} \pi_{t}
$$

Parameter $b_{1}$ shows the reaction of savings to changes in the degree of capacity utilization, while $b_{2}$ shows the sensitivity of savings to variations of the profit share in the economy. This equation differs from the standard Keynesian saving function, because it emphasizes the importance of the functional distribution of income, as opposed to just income levels.

In the model, investments depend on the expected profitability, i.e., the expected rate of profit, which implies a need to modify the rate of profit function in a way that it envelopes expectations, while in the mean time we will assume that expectations are based solely on information from previous period (adaptive expectations). Therefore, determinants of the investments function are included with a time lag t-1. Furthermore, investment function is formed from the equation (2) and with its linearization (assuming constant $\mathrm{k}$ ) it takes the following form:

$$
g_{t}^{I}=\frac{I_{t}}{K_{t}}=a_{0}+a_{1} z_{t-1}+a_{2} \pi_{t-1}
$$

Investments are also normalized by capital (Klaus, 2009), which is why they include two effects that are crucial for our empirical analysis. The first effect is the accelerator effect (parameter $a_{1}$ ) that shows the interdependence of investment and capacity utilization. On the other hand $a_{2}$ shows the effect of profits on investments. The lack of interest rate variable in the function is evident due to the analysis simplification (financial sector is not taken into account). Authors (Stockhammer and Onaran, 2004) point to a lack of interest rate, because it is not shown as an explicit determinant of investments, but its effect can be represented as a shock in the dynamics of accumulation.

Also, the impact of interest rates on the dynamics of accumulation (investments) in Croatia would most probably be insignificant, because many authors point out to a weak correlation between these two variables. Specifically, clear and unambiguous influence of interest rates on real economic activity in Croatia is nonexistent, which can be caused by certain structural features of Croatian economy such as: 
(i) dependence of private investments and enterprises on the investment activities of the state (especially in the construction sector), (ii) empirical studies of monetary transmission mechanism point to absence of interest mechanism in Croatia, and (iii) larger companies and banks have access to the international market so they can meet their financial needs for credit almost independently of the movement of domestic interest rates.

Other than profit share and aggregate demand, Kalecki (1968) emphasized the effect of technological progress on investment. In order to be able to simulate the effects of technological progress on investment activity, equation (4) is expanded by labor productivity $x_{t}$ which is directly related to the costs of production, and thus the rate of savings and profitability so it could have a significant impact on investment.

Therefore, the final form of investment function in closed economy model is:

$$
g_{t}^{I}=\frac{I_{t}}{K_{t}}=a_{0}+a_{1} z_{t-1}+a_{2} \pi_{t-1}+a_{3} \pi_{t-1}
$$

If the equilibrium condition in the goods market holds, savings are equal to investments, resulting with the following equilibrium capacity utilization function (combining equations (3) and (5)):

$$
\begin{aligned}
& g^{S}=g^{I} \\
& b_{1} z_{t}+b_{2} \pi_{t}=a_{0}+a_{1} z_{t-1}+a_{2} \pi_{t-1}+a_{3} x_{t-1} \\
& z_{t}^{I S}=\frac{1}{b_{1}}\left(a_{0}+a_{1} z_{t-1}+a_{2} x_{t-1}+a_{2} \pi_{t-1}-b_{2} \pi_{t}\right)
\end{aligned}
$$

Increasing the share of profits negatively affects aggregate consumption through reduction of real wages share in the distribution of income, so the contemporaneous effect of redistribution towards profits is negative $(-b \downarrow 2)$ in this model. However, in the longer term (i.e. lagged effects) the share of profits will also influence firm expectations as the increase in the share of profits results in an increase of return and retained earnings that can be reinvested, so we can expect that higher profits will lead to increase in capital accumulation and capacity utilization. Hence, the net effect of changes in the share of profit in a closed economy depends on the prespecified relative sensitivity of consumption and investment. If the contraction of consumer spending is higher than future investment growth, increase in the share of profits has a negative impact on the degree of capacity utilization $(\partial z / \partial \pi<0)$. In that case we can say that analyzed economy has stagnationist regime of growth. If the increase of the profit share has a positive effect on the degree of capacity utilization, we would have an accelerationist regime (Sawyer, 2009). However, in contrast to closed, in an open economy, this problem is ambiguous. 
Impact of changes in profit share on capacity utilization is manifested through an additional mechanism, which are net exports. Specifically, there can be a sufficient reduction of real wages in terms of functional distribution (between wages and profits), but also in absolute terms, which can lead to improved competitiveness of the economy and so net exports.

$$
n x_{t}=-h_{1} z_{t}+h_{2} \pi_{t}
$$

Therefore, if the model contains a function of net exports $n x_{t}$ capacity utilization function (8) takes the form:

$$
z_{t}^{I S}=\frac{1}{b_{1}+h_{1}}\left(g_{t}+\left(h_{2}-b_{2}\right) \pi_{t}\right)
$$

After the final adjustment of capacity utilization function, through which theoretical background we empirically observe behavior of Croatian economy, it is necessary to further define the final form of investment function which will help us to investigate accumulation regime characteristics in Croatia. More accurately, we will attempt to empirically validate whether accumulation of capital is led (initiated) by profits or by wages.

Therefore, if the equation (10), which represents the final form of the capacity utilization function in open economy, is inserted into equation (5), which is the equation of investments for a closed economy, we get the following equation of investments for an open economy since it includes net exports:

$$
g_{t}^{I}=a_{0}+\frac{a_{1}}{b_{1}+h_{1}} g_{t-1}+\left(a_{2}+a_{1} \frac{h_{2}-b_{2}}{b_{1}+h_{1}}\right) \pi_{t-1}+a_{3} x_{t-1}
$$

Depending on the sign in parenthesis $a_{2}+a_{1} \frac{h_{2}-b_{2}}{b_{1}+h_{1}}$, an increase in the profit share may increase or decrease the accumulation dynamics in the economy.

If $a_{2}+a_{1} \frac{h_{2}-b_{2}}{b_{1}+h_{1}}>0$ (i.e. $\partial g_{t}^{I} / \partial \pi_{t-1}>0$ ), impact of profits on growth is positive and this type of accumulation is colloquially known as profit led accumulation. The opposite regime in which the increase in the profit share leads to weakening of investments due to the strong contractionary effect on consumption (and through income mechanism on investments) is called a wage led accumulation regime.

Empirical analysis answers whether the economy is represented by "wage-led" or "profit-led" regime, and it is one of the main objectives of this paper. In addition, it is necessary to further explain other variables used in the empirical part of the paper, that is, to expose the theoretical framework of their interdependence which is analyzed as a system. 
The profit share is undoubtedly determined by trends and changes in the labor market. Specifically, the prevailing unemployment rate $u$ partly reflects the bargaining power of workers (which is a decreasing function of the unemployment rate). Therefore, the wage share is expected to increase as unemployment rate decreases. Also, an important determinant of profits, according to Stockhammer and Onaran (2004), are capacity utilization and labor productivity, and since they have already been explained, we will use them to define the profit share function:

$$
\pi_{t}=d_{0}+d_{1} z_{t}+d_{2} u_{t-1}+d_{3} x_{t}
$$

Parameter $d 1$ therefore indicates the effect of the capacity utilization $z_{t}$ on the profit share, $d 2$ represents the effect of bargaining power and $d 3$ labor productivity effect $x_{t}$. The effect of unemployment on profit share is modeled in the spirit of Kalecki (1954). The expected sign of $d 2$ is positive, as according to Kalecki (1954) increased unemployment decreases the bargaining power of labor and thus increases the degree of monopoly power of firms. This increase in market power increases the profit share of the firms. Kalecki argued that unemployment from previous periods is a more relevant determinant of this monopoly power. He recognized the fact that wage pressure need not immediately translate into higher wage share, but may also be reflected in increased inflation. Hence, it is possible that unemployment affects the profit share with a lag. Parameter $d 3$ is nonzero usually when wages are imperfectly indexed to growth in labor productivity, i.e. when wages rise faster or slower than productivity (which is the case in Croatia).

Although Bowles and Boyer (1995) suggest that the unemployment and capacity utilization move parallel, and are therefore represented by the same variable, in this paper (as in Stockhammer and Onaran, 2004), this phenomenon will be separated both in the theoretical and empirical segment. Unemployment rate function is supporting this argument, since it is determined by capacity utilization $z$ and accumulation $g$ which are goods market variables. Along with them, we also perceive labor productivity $x$, the profit share $\pi$ and the lagged value of the unemployment rate itself (which stems from Okun's law) as determinants of unemployment. It then takes the form:

$$
u_{t}=e_{0}-e_{1} \Delta z_{t}-e_{2} \pi_{t}+e_{3} u_{t-1}-e_{4} g_{t}+e_{5} x_{t}
$$

The equation assumes the negative impact of changes in the degree of capacity utilization, the profit share, and capital accumulation on unemployment. In the end, the only function left for analytical defining is the function of labor productivity.

Labor productivity (equation 14) is determined by technology and capital used in production. This model avoids explicit modeling of technological progress, so it is assumed to be exogenous $t_{0}$. Therefore, the two variables that determine labor productivity are capital accumulation $g$ and the degree of capacity utilization $z$.

$$
x_{t}=t_{0}+t_{1} g_{t}+t_{2} z_{t}
$$




\subsection{Econometric model}

The initial step in the analysis is the standard (reduced form) VAR model with constant and 5 endogenous variables with 2 lags (based on LR, FPE and AIC criteria), which is derived from the structural model:

$$
B X_{t}=\Gamma_{0}+\Gamma_{1} X_{t-1}+\ldots+\Gamma_{4} X_{t-4}+u_{t}
$$

By multiplying the expression (15) with the inverse of the matrix B we get reduced form model:

$$
X_{t}=A_{0}+A_{1} X_{t-1}+\ldots+A_{4} X_{t-4}+e_{t}
$$

where $A_{i}=B^{-1} \Gamma_{i}, e_{t}=B^{-1} u_{t}$.

$X_{t}$ vector contains current values of endogenous variables in the model and vectors $X_{t-1}$ contain their lagged values. Endogenous variables used in estimated model (16) are AKUM - capital; JAZ - income gap, UP - the share of profits in national income, NEZAP - unemployment rate; PROD - labor productivity growth rate. Apart from constant, additional exogenous variable is dummy variable which takes the value 1 from the beginning of the crisis in the fourth quarter of 2008 in order to partially mitigate the effects of a structural break in the series.

To identify the structural model, which we will use in the empirical analysis, we have to impose $\frac{n^{2}-n}{2}$ restrictions on matrix $\mathrm{B}$, where $n$ represents the number of endogenous variables in the model (Lutkepohl, 2005). Since there are five endogenous variables included in the model, we have to impose 10 restrictions which are based on the equations derived from theoretical model (see eq. 10-14 in Appendix 1).

Based on these equations the relationship between reduced and structural residuals may be shown the following way:

$$
\left[\begin{array}{c}
u_{A K U M, t} \\
u_{J A Z, t} \\
u_{U P, t} \\
u_{N E Z, t} \\
u_{P R O D, t}
\end{array}\right]=\left[\begin{array}{ccccc}
b_{11} & 0 & 0 & 0 & 0 \\
b_{21} & b_{22} & 0 & 0 & 0 \\
0 & b_{32} & b_{33} & 0 & b_{35} \\
b_{41} & b_{42} & b_{43} & b_{44} & b_{45} \\
b_{51} & b_{52} & 0 & 0 & b_{55}
\end{array}\right]\left[\begin{array}{c}
e_{A K U M, t} \\
e_{J A Z, t} \\
e_{U P, t} \\
e_{N E Z, t} \\
e_{P R O D, t}
\end{array}\right]
$$

Given the theoretical limitations, this system is over-identified by one degree of freedom, but the LR test for over-identification ( $p$-value 0.29 ) shows that we cannot accept the alternative hypothesis of over-indentified model, as in Stockhammer and Onaran (2004) so this identification scheme can be used for model estimation. The current relationship between the reduced and structural innovation is based on the theoretical model presented in the first part. For example, according to 
unemployment function (eq. 13) the error term of unemployment $(e \downarrow(N E Z, t))$ can be represented as linear combination of structural innovations of accumulation $(\in \downarrow(A K U M, t))$, output gap $(\in \downarrow(J A Z, t))$, profit share $(\in \downarrow(U P, t))$ and labor productivity $(\in \downarrow(P R O D, t))$.

For Model 15 we conducted tests of adequacy and stability and the results are shown in Appendix 2. Results of corresponding LM test indicated that the assumption of the absence of autocorrelation of residuals cannot be rejected at the level of statistical significance of 5\%, except for the seventh lag where it is not possible to reject the assumption at the significance level of $1 \%$, which is not a significant problem in the model (Stockhammer and Onaran, 2004). Jarque-Bera test of normality of residuals shows that all the residuals are normally distributed. White's test for heteroscedasticity shows that the null hypothesis of homoskedasticity can be accepted at all levels of significance. Test of the stability of the VAR model also indicates the appropriateness of the model since all parameters of characteristic polynom are inside the unit circle.

\section{Data explanation and empirical analysis}

Since there is no any publicly available estimate of capital series, in this paper we follow methodology presented in Drezgic (2008) and estimate physical capital series using perpetual inventory method (PIM), based on data from the National Accounts of the Central Bureau of Statistics. Initial values of capital are approximated by the assumption of capital output ratio of 3 . This choice can also be justified by the fact that our calculations show that the share of gross operation surplus in total income is around $1 / 3$, which is inverse of $\mathrm{K} / \mathrm{Y}$ ratio.

The income gap is calculated as the deviation of gross value added from long-term trend estimated by HP filter, which is a proxy for capacity utilization. This approach is in line with wide definition of capacity utilization used in literature (eg. formal definition by OECD): deviation of real output from the potential level. Also, in line with Keynesian economics, we believe that in the short run (which is the focus of our paper) business cycles are mostly generated by changes in aggregate demand.

Profit share in income is approximated by the share of gross operating surplus in gross value added, according to Eurostat data. We use gross operating surplus because this approach is common in literature. Also, in terms of "pure profit" we see mixed income of crafts and sole proprietorships more as labor income than "capitalist rent or profit". The unemployment rate is taken from the database of the Central Bureau of Statistics and represents the registered unemployment series. Labor productivity is estimated as ratio of gross value added and the total number of employees according to the statistics of the Central Bureau of Statistics. Time 
series are seasonally adjusted (where needed) using X-12 ARIMA and deflated by the implicit deflator with base year 2005. Data refer to the period from the first quarter of 2000 to the second quarter of 2012. Profit share and proxy for capacity utilization are graphically presented in Figure 1 and Figure 2 (other series can be found in Appendix 4).

Figure 1: Profit share

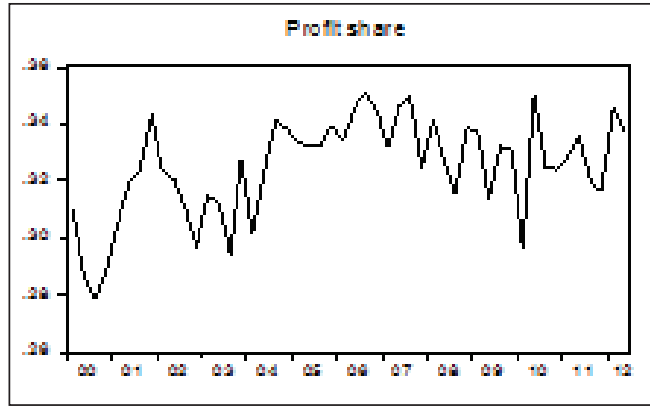

Source: Authors
Figure 2: Capacity utilization

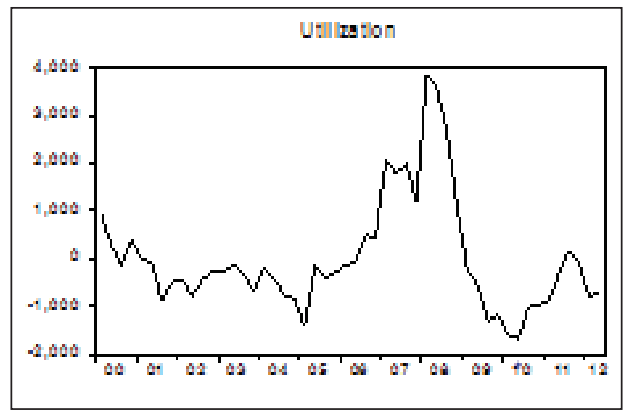

Source: Authors

According to Lutkepohl (2005), due to the assumption of stability of AR process, at the beginning of the VAR analysis it is important to examine the stationarity of the variables used. For this purpose, we conducted augmented Dickey-Fuller unit root test (Table 1), following Enders (1995).

Table 1: Unit root tests

\begin{tabular}{|l|r|r|l|r|r|r|}
\hline \multirow{2}{*}{$\begin{array}{c}\text { Variable } \\
\text { p-value }\end{array}$} & \multicolumn{3}{|c|}{ Level } & \multicolumn{3}{c|}{$1^{\text {st }}$ Difference } \\
\cline { 2 - 8 } & Intercept & Trend and intercept & None & Intercept & Trend and intercept & None \\
\hline AKUM & 0.6044 & 0.984 & 0.7613 & 0 & 0 & 0 \\
\hline JAZ & 0.2408 & 0.5367 & 0.0326 & 0 & 0 & 0 \\
\hline UP & 0.0666 & 0.274 & 0.8924 & 0 & 0 & 0 \\
\hline NEZ & 0.2654 & 0.6648 & 0.3467 & 0 & 0 & 0.0076 \\
\hline PROD & 0.3938 & 0.995 & 0.9879 & 0 & 0 & 0.0069 \\
\hline
\end{tabular}

Source: Authors

Since the variables showed $\mathrm{I}(0)$ properties on the significance level of $5 \%$, they were differentiated in order to meet the stability assumption of VAR model I(1). 


\section{Results and discussion}

Given that VAR is a system in which all variables are endogenous and usually contains more lags, it is insufficient to analyze the corresponding parameter from the regression equation in order to determine the effect one variable has on the other. The change in one variable influences all variables in the system, therefore there is no ceteris paribus assumption. Hence, in the analysis of the interrelationship between variables, impulse response functions are used. They show a dynamic "response" of each of the endogenous variables to each of the other endogenous variables in the system (Bahovec and Erjavec, 2009). Appendix 2 contains output of the impulse response functions for all the endogenous variables in the model. Dashed lines show the confidence intervals of two standard errors, i.e. level of significance of $95 \%$.

The direct result of the presented theoretical model is that changes in capital accumulation and capacity utilization are influenced by changes in profit share of income. These effects can be seen in Figures $2 \mathrm{a}$ and $2 \mathrm{~b}$.

Figure 2a: The effect of increased profit share in national income on capital accumulation

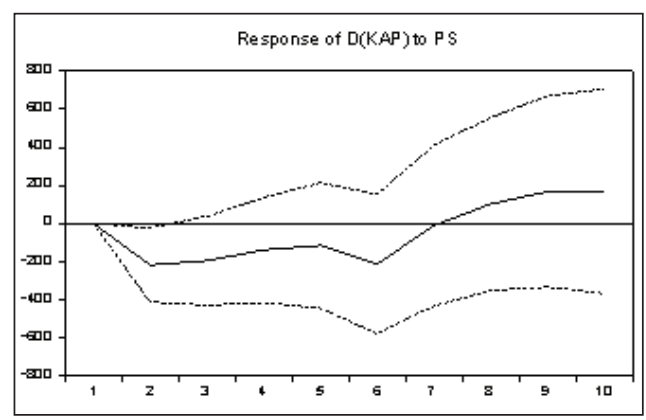

Figure 2b: The effect of increased profit share in national income on capacity utilization

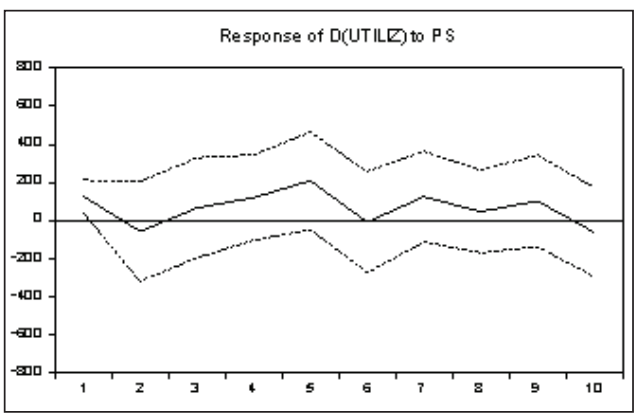

Source: Authors

The shock of increased profit share in national income of one standard deviation decreases accumulation of capital (Figure 2a). The result is statistically significant two quarters from initial shock. This reaction implies that accumulation in Croatia in the analyzed period was wage-led.

However, Figure $2 \mathrm{~b}$ shows that the shock in profit share of national income increases capacity utilization in the first period. This means that in the short run (one quarter) (i) the effect of increased profit share (or decreased labor share due to lower wages) on the competitiveness of the economy and the resulting increase in exports and capacity utilization is greater than (ii) the negative effect of increased 
profit share on accumulation of capital and the resulting decrease of capacity utilization and (iii) negative effect of increased profits on consumption and resulting decrease in capacity utilization. Thus, due to the assumptions of theoretical model, it can be stated that Croatia has an exhilirationist (accelerationist) regime of growth, although the impulse response indicates that these effects are statistically significant only in the first period after the shock, so this result should be taken with the degree of caution.

Given that Croatia is a small open economy, the significant impact of exports on capacity utilization is expected. For example, Krznar and Kunovac (2010) show that economic activity in main trade partner economies (EU) is the most important determinant of economic activity in Croatia. On the other hand, the effect of exports on investment is smaller than the effect of consumption on investment, which is expected due to the large share of consumption and relatively low share of exports in gross domestic product. Mechanisms through which net exports influence investment less than capacity utilization are left for future research. Because the increase in the profit share increases capacity utilization but, on the other hand, decreases investments, which influence the long run growth of an economy, the final effect of functional income distribution on economic growth remains to be determined.

As for the unemployment, impulse response functions imply that unemployment in observed period was mostly determined by demand factors and to a lesser extent by income distribution, while the supply side effects are indeterminate. Figure 3a shows that a positive shock of one standard deviation in capacity utilization decreases unemployment during three quarters after the shock. This leads to a conclusion that aggregate demand has a statistically significant and negative effect on unemployment in Croatia. Although this is a relatively intuitive conclusion, in Croatia there is no considerable amount of research papers (publicly available) which assessed the interrelationship between unemployment and aggregate demand.

On the aggregate supply side, a shock in productivity of labor (Figure 3b) decreases unemployment in one period after the shock. This implies the positive effect of technological progress on employment. However, one needs to be careful before drawing any definite conclusion by using this variable. The growth in productivity of labor may be caused by capital deepening. As it can be seen from the Appendix 2, positive shock in capital accumulation increases labor productivity. It is interesting to note that the effect of a shock in aggregate demand on unemployment is longer lasting than the effect of a shock in productivity growth. 
Figure 3a: The effect if an increase in capacity utilization on unemployment

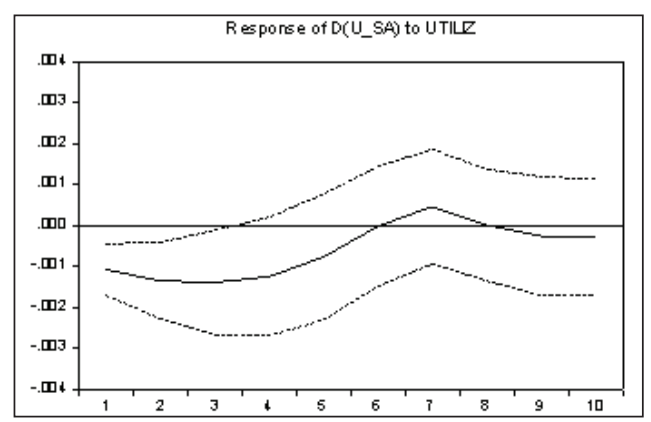

Figure 3b: The effect of an increase in labor productivity on unemployment

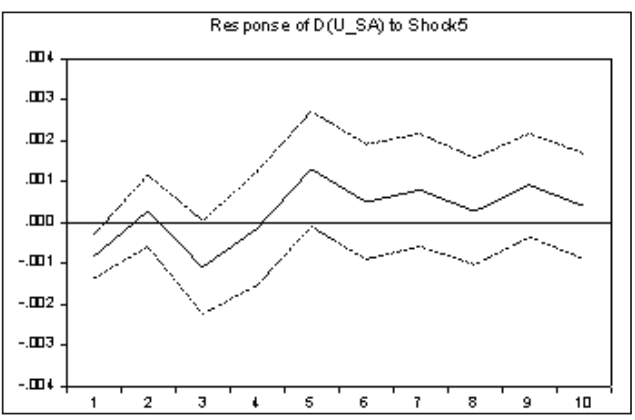

Figure 3c: The effect of an increase in profit share in national income on unemployment

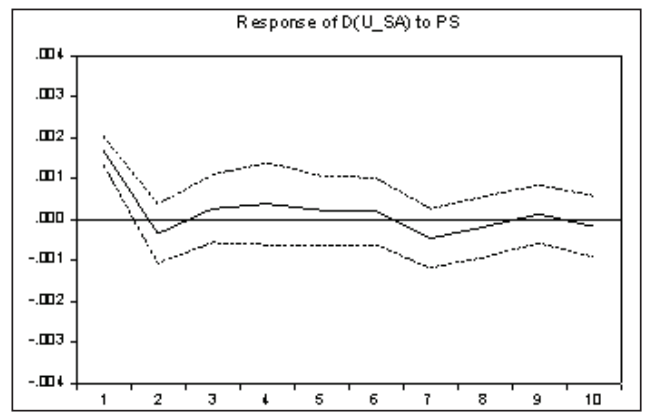

Source: Authors

In Figure 3c, one can see that the shock in the profit share increases unemployment in the short run. The usual result of neoclassical labor market theory is that the reduction in wages decreases unemployment, because firms can employ more workers if the wages are lower. If we use one minus profit share, as a proxy for wages, then we can argue that on the aggregate level the reduction in wages results in increased unemployment. ${ }^{6}$ This conclusion is opposite to the implications of the neoclassical labor market model. ${ }^{7}$

$\overline{6}$ According to the assumptions of the neoclassical production function $\mathrm{Y}=\mathrm{AK}^{\alpha} \mathrm{L}^{1-\alpha}$ and the Euler theorem, it can be shown that exponents $\alpha$ and 1- $\alpha$ represent labor and capital share in national income, in which national income is entirely divided between labor and capital.

7 There is a series of models which can be described as neoclassical which result in the negative effect of wage reduction on unemployment (i.e. efficiency wage model). Here we refer to the standard (classical) model of the labor market which is widely represented in economic literature (where Ls and Ld depend only on W/P). 


\section{Conclusion}

Our main hypothesis, that the accumulation of capital in Croatia was primarily determined by income from labor, was confirmed in empirical analysis. We also found that labor market dynamics was dominantly influenced by demand side shocks and that positive effects of the rise in exports, resulting from the gain in competitiveness (after reducing wage share in income) outweigh negative effects of weaker demand on the capacity utilization. Less expected is our final result which shows that increase in profit share in national income increases unemployment, which runs contrary to the conclusions of neoclassical labor market model that predicts that decline in wages results with increase of employment. The main contribution of this research is that it represents the first attempt of the analysis of Croatian economy in the heterodox macroeconomic framework and that it provides first empirical assessment of the effects of functional distribution of income on economic activity in Croatia. It is important to emphasize that the interpretation of these results should be approached with caution because of several methodological limitations of this type of research. Length, frequency and quality of used data can significantly affect the conclusions of our model. Number of variables in the model, number of lags and structural breaks in data could influence the quality of results due to the fact that we used quarterly data that provided 50 observations and that Croatian economy was in recession for approximately $30 \%$ of observed period. Robustness of the model was tested by replacing the variable of capital accumulation with the share of capital investment in the gross value added, which did not significantly affect the basic conclusions of the model.

The key policy issue and recommendations stem from the fact that capital accumulation and labor dynamics in Croatia were dominantly determined by demand side factors. However, as domestic demand is currently constrained by high debt levels, i.e. macroeconomic budget constraint became binding, in our opinion export share increase should become policy priority because our results show that exports have an important positive impact on the capacity utilization. To the extent that increase in exports might require decline in the relative share of labor, negative impact on the investments in non-tradable sector (due to the fall in domestic demand) would need to be offset with higher investments in tradable sector.

\section{References}

Bahovec, V., Erjavec, N. (2009) Uvod u ekonometrijsku analizu, Zagreb: Element.

Bhaduri, A., Marglin, S. (1990) "Unemployment and the Real Wage: The Economic Basis for Contesting Political Ideologies", Cambridge Journal of of Economics, Vol. 14, pp. 375-393. 
Bowles, S., Boyer, R. (1995) "Wages, Aggregate Demand, and Employment in an Open Economy: An Empirical Investigation”, in: Epstein, G. A., Gintis, H. M. (2011) Macroeconomic Policy after the Conservative Era: Studies in Investment, Saving and Finance, Cambridge University Press, New York.

Drezgić, S. (2008) "The effects of public sector investments on economic growth of Croatia", Young Economists' Seminar to $14^{\text {th }}$ Dubrovnik Economic Conference: Proceedings Zagreb: Croatian National Bank, 2008., pp. 1-49.

Enders, W. (1995) Applied Econometric Time Series, New York, John Wiley \& Sonc, Inc.

Gordon, D. (1995a) "Putting the gorse (back) before the cart: Disentangling the macro relationship between investment and saving", in: Epstein, G. A., Gintis, H. M. (2011) Macroeconomic Policy after the Conservative Era: Studies in Investment, Saving and Finance, Cambridge University Press, New York, pp. 335-383.

Gordon, D. (1995b) "Growth, distribution, and the rules of the game: social structuralist macro foundations for a democratic economic policy", in: Epstein, G. A., Gintis, H. M. (2011) Macroeconomic Policy after the Conservative Era: Studies in Investment, Saving and Finance, Cambridge University Press, New York, pp. 335-383.

Hein, E., Ochsen, C. (2003) "Regimes of interest rates, income shares, savings, and investment: a Kaleckian model and empirical estimations for some advanced OECD-economies", Metroeconomica, Vol. 54, No. 4, pp. 404-433.

Hein, E., Schoder, C. (2009) "Interest rates, distribution and capital accumulation - A Post - Kaleckian perspective on the US and Germany", Institute for International Political Economy Berlin, Working Paper, No. 04/2009.

Kalecki, M. (1954) "Theory of Economic Dynamics”, in: Osiatynski, J. (Ed.), Collected works of Michal Kalecki. Clarendon Press, Oxford.

Kalecki, M. (1968) "Trend and business cycle”, in: Osiatynski, J. (Ed.), Collected works of Michal Kalecki. Clarendon Press, Oxford.

Klaus, D. (2009) "A system dynamics approach to the Bhaduri - Marglin model". The $27^{\text {th }}$ International Conference of the System Dynamics Society. Albuquerque: System Dynamic Society.

Krznar, I., Kunovac, D. (2010) “Utjecaj vanjskih šokova na domaću inflaciju i BDP”, Istraživanja I-28, Hrvatska narodna banka.

Lutkepohl, H. (2005) New Introduction to Multiple Time Series Analysis, Berlin, Springer.

Onaran, Ö, Stockhammer, E. (2005) “Two different export-oriented growth strategies: accumulation and distribution a la Turca and a la South Korea" Emerging Markets Finance and Trade, 41(1), pp. 65-89.

Sawyer, M. (2009) The central core of heterodox macroeconomics. U J. P. Goldstein, M. G. Hillard, Heterodox Macroeconomics: Keynes, Marx and Globalization (pp. 24-35). Abingdon: Routledge Advances in Heterodox Economics. 
Stockhammer, E., Onaran, O. (2004) “Accumulation, distribution and employment: a structural VAR approach to a Kaleckian macro model", Strucural Change and Economic Dynamics, Vol. 15, No. 4, pp. 422-446.

Stockhammer, E., Onaran, O., Ederer, S. (2009) "Functional Inocme Distribution and Aggregate Demand in the Euro Area", Cambridge Journal of Economics, Vol. 33, No. 1, pp. 139-159. 


\title{
Funkcionalna distribucija dohotka i ekonomska aktivnost u Hrvatskoj: Postkejnezijanski pristup
}

\author{
Boris Vujčić ${ }^{1}$, Milan Deskar-Škrbić ${ }^{2}$, Zvonimir Ratkovski ${ }^{3}$, Jurica Zrnc ${ }^{4}$
}

\begin{abstract}
Sažetak
U radu se testiraju pretpostavke i zaključci kaleckijanskog makroekonomskog modela na podacima o odredenim segmentima realnog sektora hrvatskog gospodarstva u razdoblju od 2000.-2012. godine. Cilj rada je kvantificirati učinke promjene u funkcionalnoj distribuciji dohotka na odabrane makroekonomske varijable u Hrvatskoj te pokušati odgovoriti pitanja: (i) je akumulacija kapitala u Hrvatskoj potaknuta dohotcima od rada ili kapitala (engl. wage-led accumulation ili profit-led accumulation), (ii) ima li Hrvatska stagnirajući ili akcelerirajući režim rasta, (iii) jesu li kretanja na tržištu rada pod snažnijim utjecajem promjena na strani agregatne potražnje ili ponude. Rezultati rada pokazuju da je, prema pretpostavkama teorijskog modela, akumulacija kapitala u Hrvatskoj u analiziranom razdoblju bila vođena dohotcima od rada. Međutim, rezultati pokazuju i kako je u promatranom razdoblju Hrvatska imala akcelerirajući režim rasta, tj. da je utiliziranost kapaciteta bila vođena dohotcima od profita. Nezaposlenost je dijelom određena faktorima sa strane potražnje te udjelom profita, dok je utjecaj promjena na strani ponude moguć, ali neutvrđen. Zbog nejednoznačnosti rezultata potrebno je provesti daljnja istraživanja doprinosa rada i kapitala ekonomskom rastu u Hrvatskoj.
\end{abstract}

Ključne riječi: funkcionalna distribucija dohotka, postkejnezijanski makroekonomski model, hrvatsko gospodarstvo, SVAR

JEL klasifikacija: E12, E21, E25

1 Doktor ekonomskih znanosti, Guverner, Hrvatska narodna banka, Trg hrvatskih velikana 3, 10000 Zagreb, Hrvatska; Izvanredni profesor, Sveučilište u Zagrebu, Ekonomski fakultet, Trg J. F. Kennedyja 6, 10000 Zagreb, Hrvatska. Znanstveni interes: EMU, euroizacija, tržište rada u EU. Tel.:014564 555.E-mail: boris.vujcic@hnb.hr.

${ }^{2}$ Mag.oec., Makroekonomski analitičar, Erste\&Steiermarkische bank d.d., Ivana Lučića 2, 10000 Zagreb, Hrvatska. Znanstveni interes: makroekonomija financijskih tržišta, ekonomska politika, javne financije i bankarstvo.Tel.: 091580 2592.E-mail: mdskrbic@erstebank.hr.

${ }^{3}$ Mag.oec., Analitičar, Deloitte Hrvatska, Radnička cesta 80, 10000 Zagreb, Hrvatska. Znanstveni interes: makroekonomija, heterodoksna ekonomska teorija, ekonomska politika. Tel.: 0981871 839.E-mail: zvonimir.ratkovski@gmail.com.

${ }^{4}$ Mag.oec., Stručni suradnik u Odjelu za gospodarska kretanja i proračun, Hrvatska narodna banka, Trg hrvatskih velikana 3, 10000 Zagreb, Hrvatska. Znanstveni interes: makroekonomija, ekonomski rast, tržište rada, ekonomska povijest.Tel.: 098959 3482.E-mail:jurica.zrnc@hnb.hr. 


\section{Appendices}

Appendix 1: Theoretical assumptions for identification of structural model

(i) accumulation (eq. 11):

$$
g_{t}^{I}=a_{0} \frac{a_{1}}{b_{1}+h_{1}} g_{t-1}+\left(a_{2}+a_{1} \frac{h_{2}-b_{2}}{b_{1}+h_{1}}\right) \pi_{t-1}+a_{5} x_{t-1}
$$

(ii) capacity utilization (eq. 10):

$$
z_{t}^{I S}=\frac{1}{b_{1}+h_{1}}\left(g_{t}+\left(g_{t}+\left(h_{2}-b_{2}\right) \pi_{t}\right)\right.
$$

(iii) profit share (eq. 12):

$$
\pi_{t}=d_{0}+d_{1} z_{t}+d_{2} u_{t-1}+d_{3} x_{t}
$$

(iv) unemployment rate (eq. 13):

$$
u_{t}=e_{0}-e_{1} \Delta z_{t}-e_{2} \pi_{t}+e_{3} u_{t-1}+e_{4} g_{t}+e_{5} x_{t}
$$

(v) labor productivity (eq. 14):

$$
x_{t}=t_{0}+t_{1} g_{t}+t_{2} z_{t}
$$

Appendix 2: Model adequacy tests

Stability test

\begin{tabular}{|c|c|}
\hline Root & Modulus \\
\hline 0.87203 & $\mathbf{0 . 8 7 2 0 3}$ \\
\hline $0.696704-0.248491 \mathrm{i}$ & $\mathbf{0 . 7 3 9 6 9 2}$ \\
\hline $0.696704+0.248491 \mathrm{i}$ & $\mathbf{0 . 7 3 9 6 9 2}$ \\
\hline$-0.367716-0.565961 \mathrm{i}$ & $\mathbf{0 . 6 7 4 9 2 7}$ \\
\hline$-0.367716+0.565961 \mathrm{i}$ & $\mathbf{0 . 6 7 4 9 2 7}$ \\
\hline $0.151958-0.480027 \mathrm{i}$ & $\mathbf{0 . 5 0 3 5 0 5}$ \\
\hline $0.151958+0.480027 \mathrm{i}$ & $\mathbf{0 . 5 0 3 5 0 5}$ \\
\hline-0.398167 & $\mathbf{0 . 3 9 8 1 6 7}$ \\
\hline-0.288612 & $\mathbf{0 . 2 8 8 6 1 2}$ \\
\hline$-0.175261-0.205202 \mathrm{i}$ & $\mathbf{0 . 2 6 9 8 5 9}$ \\
\hline$-0.175261+0.205202 \mathrm{i}$ & $\mathbf{0 . 2 6 9 8 5 9}$ \\
\hline 0.256378 & $\mathbf{0 . 2 5 6 3 7 8}$ \\
\hline
\end{tabular}

LM autocorreation test

\begin{tabular}{|c|c|c|}
\hline Lags & LM-Stat & Prob \\
\hline 1 & 35.11133 & $\mathbf{0 . 0 8 6 2}$ \\
\hline 2 & 21.52571 & $\mathbf{0 . 6 6 3 0}$ \\
\hline 3 & 21.02170 & $\mathbf{0 . 6 9 1 4}$ \\
\hline 4 & 23.01063 & $\mathbf{0 . 5 7 6 9}$ \\
\hline 5 & 30.99098 & $\mathbf{0 . 1 8 9 3}$ \\
\hline 6 & 36.75410 & $\mathbf{0 . 0 6 0 9}$ \\
\hline 7 & 43.74381 & $\mathbf{0 . 0 1 1 6}$ \\
\hline 8 & 21.03475 & $\mathbf{0 . 6 9 0 7}$ \\
\hline 9 & 30.28507 & $\mathbf{0 . 2 1 3 8}$ \\
\hline 10 & 24.13380 & $\mathbf{0 . 5 1 1 7}$ \\
\hline
\end{tabular}

White heteroskedasticity test

\begin{tabular}{|c|c|}
\hline Chi-sq & Prob. \\
\hline 634.6207 & $\mathbf{0 . 2 8 3 5}$ \\
\hline
\end{tabular}

Cholesky (Lutkepohl) normality test

\begin{tabular}{|c|c|c|c|}
\hline Component & $\begin{array}{c}\text { Jarque- } \\
\text { Bera }\end{array}$ & df & Prob. \\
\hline 1 & 0.497840 & 2 & 0.7796 \\
\hline 2 & 1.936348 & 2 & 0.3798 \\
\hline 3 & 1.448156 & 2 & 0.4848 \\
\hline 4 & 2.164865 & 2 & 0.3388 \\
\hline 5 & 0.413599 & 2 & 0.8132 \\
\hline Joint & 6.460809 & 10 & $\mathbf{0 . 7 7 5 2}$ \\
\hline
\end{tabular}

Source: Authors' calculations 
Boris Vujčić et al. $\bullet$ Functional distribution of income and economic activity in Croatia...

Zb. rad. Ekon. fak. Rij. • $2014 \cdot$ vol. $32 \cdot$ sv. $1 \cdot 53-73$

Appendix 3: Impulse response functions
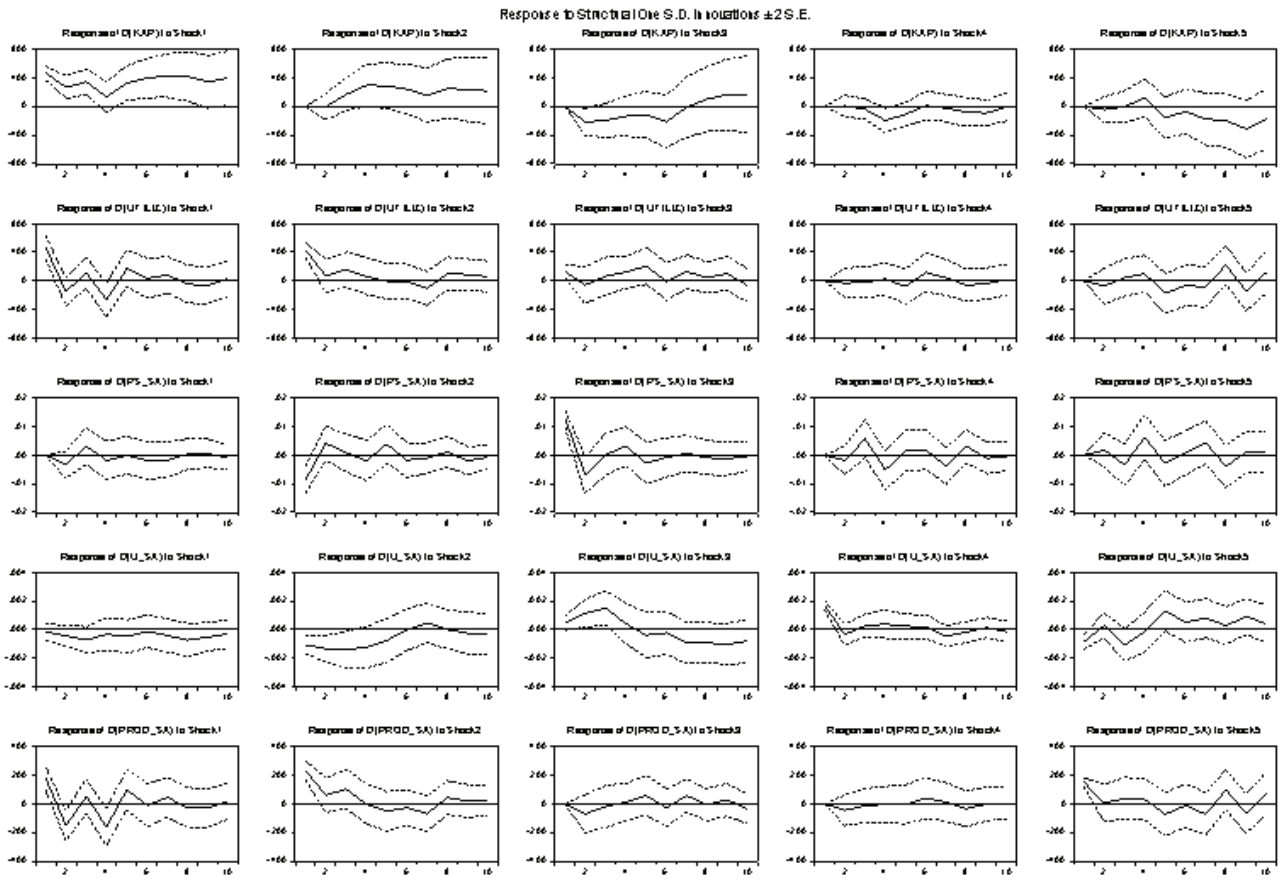

Source: Authors' calculations

Appendix 4: Graphical presentation of the data
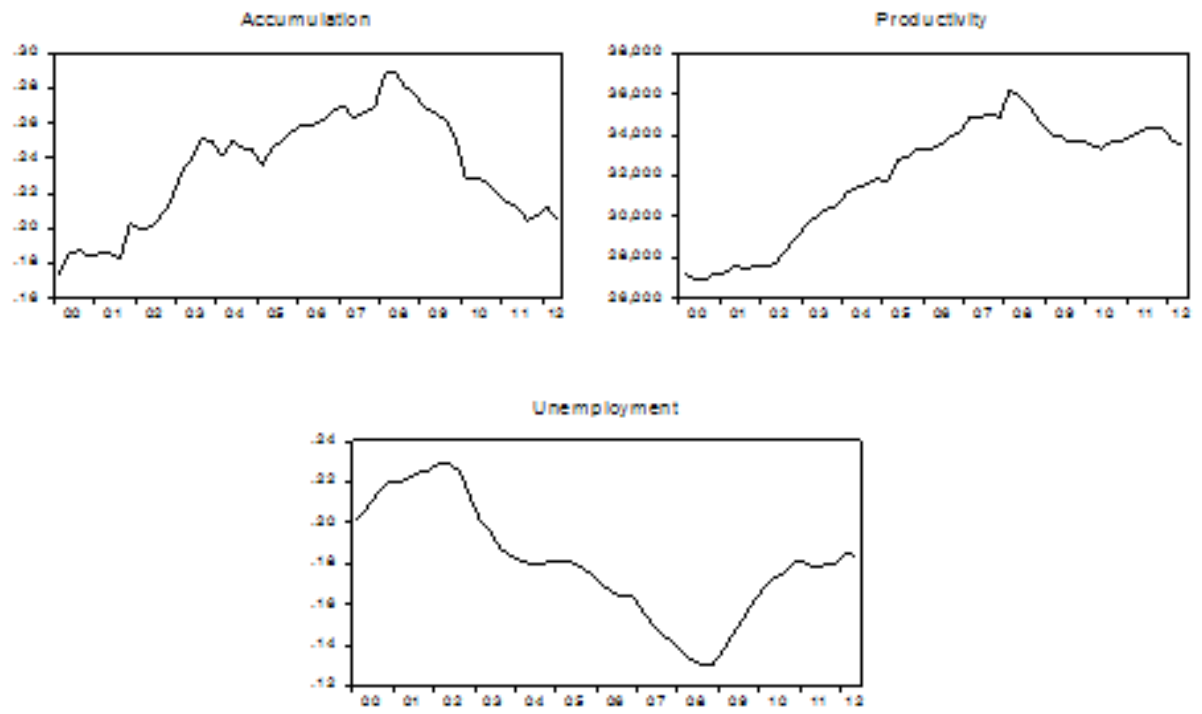